\title{
Modern Technologies and Applications of ICT in the Training Process of Teachers-Philologists
}

\author{
Inna S. Berkeshchuk ${ }^{1}$, Iryna V. Shcherbak ${ }^{2}$, Nataliia M. Shkvorchenko ${ }^{3}$, Tetiana E. Masytska ${ }^{4} \&$ Igor V. Chornyi $^{5}$
}

${ }^{1}$ Department of Ukrainian Language, Faculty of Ukrainian Philology and Journalism, Kamyanets-Podilskyi National Ivan Ohiyenko University, Kamyanets-Podilskyi, Ukraine

${ }^{2}$ Departments Informatics, Socio-Pedagogical Sciences And Foreign Philology Faculty, Municipal Establishment "Kharkiv Humanitarian Pedagogical Academy" of Kharkiv Regional Council, Kharkiv, Ukraine

${ }^{3}$ Department of Translation and Linguistics, Faculty of Linguistics and Translation, International Humanitarian University, Odessa, Ukraine

${ }^{4}$ Departments of Ukrainian Language, Faculty of Filology and Journalism, Lesya Ukrainka Eastern European National University, Lutsk, Ukraine

${ }^{5}$ Ukrainian Studies Department, Faculty No. 2, Kharkiv National University of Internal Affairs, Kharkiv, Ukraine

Correspondence: Inna S. Berkeshchuk, Kamyanets-Podilskyi National Ivan Ohiyenko University, 61 Ohiyenko str., Kamyanets-Podilskyi, 32301, Ukraine.

Received: June 10, 2020

Accepted: August 3, 2020

Online Published: August 4, 2020

doi:10.5430/ijhe.v9n7p84

URL: https://doi.org/10.5430/ijhe.v9n7p84

\begin{abstract}
The use of online technology of an experimental, gaming, competitive nature helps unite the virtual context and the acquisition of analytical skills in an environment, where personal communication is impossible, and the learning process requires high-quality preparation and understanding of the level of acquisition of speech skills. Studies show that within the conditions of distance learning of language and literature teachers (philologists), special difficulties are caused by the study of new technologies related to speech practice, stylistics, text creation; the reason for this is the insufficient number of group and heuristic activities, work in pairs, lack of sufficient speech practice of high communicative and intellectual level. Online quizzes as a technology of competition, games aims to increase the register, level and intensity of communication; they can potentially overcome the lack of authentic communication and academic traditions in the training of philologists. The purpose of this study is to show the prospects for the use of modern information and computer technologies. Intensive informatization of the educational process has its own organizational specifics: the willingness and availability of technical capabilities not only for students - philologists, but also for the teaching staff of universities and administrations. The condition for successful informatization is the ability of teachers to effectively use all available potential. The study focuses on the use and scope, difficulties in implementing information and communication technologies, and separate competitive interactive forms in higher education of language and literature teachers in terms of distance education.
\end{abstract}

Keywords: informatization of educational process, communication technologies, pedagogical education, online quizzes, open education

\section{Introduction}

\subsection{Introduction of ICT}

The rapid pace of the society's informatization, exacerbated by quarantine restrictions, have significantly changed and accelerated the informatization rate of the educational space. The concept of open education and informatization of the educational process have been highlighted (Ivanova, 2020; Stavytska, 2015). Over the last ten years, the educational community has been actively implementing information and communication technologies at all levels of the educational process (Gorman, 2019; Vdovychyn \& Iatsyshyn, 2013). The introduction of forms of online education as part of open learning will help education find new forms of communication for distance learning, increase the effectiveness of preparing students for future activities, facilitate the process of learning and searching for information. This has become especially relevant for the training of philologists within the conditions of distance education (Koval, 2009; Mervat, 2016). Currently, information and communication technologies are used to transfer, 
accumulate and deliver a variety of content to the participants of communication - students and teaching staff. Online quizzes are one of the forms that have helped in the quarantine situation and gained popularity as a new technological tool of education. Supporters of the educational process's informatization (Ovcharuk, 2006; Villano, 2007) are convinced that game forms, the creation of groups in social networks, are implemented on the territory of the technological means of educational communication; they will help improve the standards of higher pedagogical education, especially creative directions, focusing on improving practical communicative and writing skills. Researchers, specialists from the latest tools of informatization (Buzhikov, 2011; Sereda, 2014) determine the great potential of information technology, linking it also with the intellectualization of the educational process. The feature of online quizzes lies in the fact that they offer game, competitive, multi-level methods, simultaneously covering a large number of participants, a variety of content instead of traditional (and in modern conditions not available traditional forms of learning) learning tools. High-tech teaching aids are not focused on the educator as a center of teaching, but rather - a mediator that creates favorable conditions for improving communication skills, creating authentic situations of communication in different languages, different speech scenarios. Online quizzes make it possible for a large number of students to acquire the necessary knowledge and skills without the time and money, as well as improve these skills and abilities and create their own content based on this (Kilchenko \& Romenets, n.d.; Mason, 2006). The introduction of online quizzes will facilitate distance learning of philological disciplines, increase the level of open education; it will help overcome organizational, partly financial and administrative problems of universities, raise the standards of modern education.

\subsection{Research Context: Modern Educational Technologies}

Stavytska (2015) has noted that the informatization of modern society is of global scale; the feature of this social process centers around the dominance of complex high-tech operations with information, where one of the main roles is given to communication.

Network technologies of open education are used by a number of Ukrainian universities that have joined international programs. In 2009, with the support of Microsoft in Ukraine, "The Partnership in Education" network was launched in Ukraine, which included the UK - Ukraine cooperation program (Sereda, 2011; 2014). The participants of the program were the Institute of Information Technologies and Teaching Aids of the National Academy of Pedagogical Sciences of Ukraine, Microsoft Company (the USA), WireStone Company (the USA). The results of the program were quite positive. There were 10900 Ukrainian members of the network, more than 2800 educational materials were downloaded, more than 110 effective communities were created (Network partnership in learning, n.d.; Sereda, 2014).

The initiative was taken up by a number of Ukrainian universities and analytical centers, public organizations, which have made the main goal to develop free education, to introduce modern educational technologies, as well as to modernize information and communication technologies in education. Digital transformations in solving digital literacy problems and coordination of the management of such educational systems turned out to be a particular problem. Vinnytsia State Pedagogical University (Vysotska, n.d.) uses new technologies and highly intelligent tools for learning, as well as information technologies in the educational process.

A group of philologists of Yaroslav Mudryi National Law University have presented the group on Facebook as an educational platform for learning foreign languages (Mykytiuk, Lysystska \& Melnikova, 2020). The obtained positive results testify to the effectiveness of such forms of education. The study of different levels of a foreign language in the absence of the required language environment outside the curriculum has encouraged teachers to attract the opportunities of the social network (Mervat, 2016; Tashakori \& Haghighat, 2019). The participants of the quasi-experiment have positively assessed this way of learning. At the end of the work $98 \%$ of participants have positively assessed the impact of such educational technology on the level of their knowledge and the pace of learning. Game exercises, quizzes, open tasks on Facebook and telegram communities have been part of the educational cases in such a quasi-experiment (Mykytiuk, Lysystska \& Melnikova, 2020).

Recent studies concerning the introduction of informatization of educational space (Synorub, Medynska, Poplavska, Medynska \& Poplavska, 2019), the involvement of online quiz techniques have shown the correctness and sufficient effectiveness of the involvement of technologically modern game teaching methods in distance learning. Financial resources were used for this purpose, a group of IT specialists was involved, and a number of training events were conducted. The telecommunications structure had to be improved, as well as it was necessary to create software, conditions for successful resource management, increase server capacity, communication speed, a wide range of access for users of different ranks (Sereda, 2011; Vdovychyn \& Iatsyshyn, 2013).

In 2019, universities made distance learning courses available; online quizzes occupied an important place among 
them (Mykytiuk et al., 2020; Vykhrushch et al., 2019). Website traffic during the strict quarantine has increased by many times. This means that students are interested in blended open learning. It meets the requirements of the modern world for educational content.

In 2019, a comprehensive partnership program of universities, libraries and analytical center of the Academy of Ukrainian Press began to actively introduce new technologies. In 2020, within the conditions of distance learning, NGO "Center for Analytics and Investigations», the fact-check project "BezBrehni" implements the educational project "Interactive quizzes as a tool of media literacy to counteract fake news and misinformation" with the support of the Academy of Ukrainian Press and Internews Ukraine (Mykhalchuk, 2020). The project partners include 10 institutions (regional libraries for children and youth -5 , higher education institutions -5 ). The project was also successful: $80 \%$ of project participants rated it positively, noting that it is easier to learn difficult material in the form of a game (Mykhalchuk, 2020).

Increased interest in modern information and communication technologies is caused by a number of reasons. Open learning in higher education solves many problems that have been caused by the quarantine regime introduction during a pandemic, namely: 1. great demand for knowledge without the ability of universities to provide all students with teaching, technical, program resources equally; 2. there are no spatial restrictions, the ability to deliver knowledge regardless of the location of group members; 3. opening new perspectives for young teachers and students to realize more of their opportunities; 4 . the opportunity to use and improve modern technological advances in education on their own mind.

\subsection{The Purpose of the Study}

The purpose of the study is to consider the strengths and weaknesses of online quizzes as one of the modern educational technologies of information and communication nature. In the global educational field of philologists' training, modern technological teaching methods should be introduced as part of open education. These positive and negative aspects of informatization tools' integration of the educational space into the academic environment should be specified and analyzed. In this academic paper we explore the features of online quizzes that improve the quality of higher education, provide the best result and improve the system of ICT tools in the future. In a broad sense, the investigation is motivated by consideration of practical cases of ICT, and especially gaming technologies. Let us also consider the experience of a number of Ukrainian institutions, where a constant development of new effective forms of open education takes place, forasmuch as this is the key factor in creating a modern open education in the academic environment. It is important to present the experience of open learning, distance learning, motivation, achievements, benefits and prospects for the introduction of information and communication technologies in the training process of philologists, as well as model a group of organizations, universities - participants in the application of the process of technologization of education, and determine the role of each in this process.

\section{Methodological Framework}

\subsection{Research Viewpoints: Spreading Interest in ICT Implementation}

There is a number of research articles in modern pedagogical science, which we will review. There are studies that consider the classification of ICT and methods of application in various forms of education (Goncharenko, 2011; Vdovychyn \& Iatsyshyn, 2013; Zabolotny, 2010). Such articles consider mostly positive aspects; they note the great impact of such tools on open, blended, online learning, where ICT is a very important educational approach that significantly affects online learning.

Firstly, the positive aspects of the functioning of ICT contribute to increasing the audience of users, increasing the prestige of research institutions and universities that implement them (Sereda, 2011; 2014), promoting the interest of the world community in the activities of such institutions.

Secondly, the increase in the audience is due to the fact that many ICTs are developed by prestigious institutions, universities, establishments (Mykytiuk et al., 2020; Vykhrushch et al., 2019). Well-known and respected scientists, public figures and teachers take part in these programs. Involvement in such groups makes a new participant (student, entrant, graduate student) part of a large rating movement (Ivanova, 2020).

Thirdly, ICT should be perceived as a solution to a number of problems for the use of open education, which can attract a large number of students located in different parts of the world; it overcomes physical barriers to obtaining quality education. Such programs make it possible to cover a large number of respondents with a minimum of financial costs (Bikov, 2009; Kilchenko \& Romenets, n.d.).

There are some studies that consider the motivation of learning within social groups, social electronic networks. 
Within the framework of such investigations there are studies concerning learning foreign languages by using Facebook groups, social media, Facebook communities. In the course of such studies, the evolution of motivation of students - philologists to this type of training has been considered. It has been revealed that while learning communicative, lexical-grammatical, thematic cases students are able to quickly learn not only the actual learning material, but also to acquire new technical knowledge and skills (Mervat, 2016; Mykytiuk et al., 2020).

A number of studies are devoted to the role of ICT in motivation changes during education and ideological and patriotic education of students - philologists. During the study, students' motivation has changed, interest in professional growth and desire to become successful has increased. The use of computerized forms, game forms makes it possible to master knowledge in the convenient for the student mode, to independently solve the tasks set for him (Ivanova, 2020).

A number of studies are devoted to the description and analysis of the influence of information culture, taking into account the intensification of informatization and the introduction of new high-tech educational tools (Vykhrushch et al., 2019). After the experiment, a survey has been conducted on the benefits of using high technology in training students - philologists of publishing industry direction, etc. As a conclusion, students have found online sources of learning and information to be effective and flexible. The authors consider that the benefits of electronic tools should be used to increase the level of information culture of young people (Synorub et al., 2019). This will contribute to the development of personal characteristics of specialists - linguists in the field of information technologies, information literacy during the training of teaching staff.

\subsection{General Problems in the Introduction of Educational Space's Informatization}

The introduction of ICT in the educational context also poses a number of practical, technological, financial and psychological challenges to educators. I. Stavytska has noted (Stavytska, 2015) that it is necessary to take into account the high cost of such projects: the organization of training, the use of a large number of high-tech tools, the introduction of quality organizational and methodological assistance (instruction, training of students, teachers, technical staff), creation of a software package, and also creation of an educational and methodical complex. Difficulties also arise due to the lack of ICT development methodology, lack of quality usability (Sereda, 2014). This leads to the fact that students and teachers should focus only on their own knowledge and experience, their own empirical search for ways to effectively use information technologies (Buzhikov, 2011).

The researcher determines the duration of the active process of gaining experience, the selection of new teaching methods to improve the quality of education through the application of new forms of ICT use. Kh. Sereda also identifies a number of problems that have arisen during the use of ICT in education. They include: an insufficient logistical and scientific-methodological platform; insufficient number of developed methods of using modern ICT during their application in the educational process of open education; insufficiently trained teachers and students; lack of motivational levers for teachers to use ICT. In the course of the study it has been revealed that even experienced employees do not fully understand the algorithms for working with ICT, which is noticeable during system design: potential users will not be able to formulate an algorithm for their actions. Common issues of increasing student motivation include increasing the level of individualization of education, development of distance work skills, and obstacles include: lack of motivation and technical means (see Table 1).

Table 1. General issues of ICT implementation: advantages and disadvantages (Bikov, 2009; Sereda, 2011).

\begin{tabular}{ll}
\hline \multicolumn{1}{c}{ Advantages } & \multicolumn{1}{c}{ Disadvantages } \\
\hline $\begin{array}{l}\text { Increasing students } \text { motivation to study, acquiring } \\
\text { professional skills. }\end{array}$ & $\begin{array}{l}\text { Insufficient training of teachers and students. } \\
\text { Lack of knowledge and skills in mastering ICT. }\end{array}$ \\
$\begin{array}{l}\text { Implementation of the social purpose - informatization of } \\
\text { educational process. }\end{array}$ & $\begin{array}{l}\text { The cost of using ICT. } \\
\text { Lack of personal communication between a group of } \\
\text { students and teachers. }\end{array}$ \\
$\begin{array}{l}\text { Improving the efficiency of open education processes. } \\
\text { personality. } \\
\begin{array}{l}\text { Development of skills of independent distance work with } \\
\text { educational material. }\end{array}\end{array}$ \\
$\begin{array}{l}\text { Improving the effectiveness of open education through } \\
\text { its individualization. }\end{array}$ & $\begin{array}{l}\text { Limited access to technical means and means of } \\
\text { communication. } \\
\text { support. }\end{array}$ \\
\hline
\end{tabular}




\section{Results}

\subsection{ICT as Part of Integrated Open Education in the Context of Training Philologists at Higher Educational Institutions}

Open education is possible in an open learning environment as a complex harmonious combination of online and independent learning, information and communication technologies and computer-based tools (Vdovychyn \& Iatsyshyn, 2013). Such training is aimed at obtaining quality education without direct interaction, mainly replacing it with online forms of training.

\subsection{Positive Prospects for the Use of ICT in an Open System-Online Quizzes}

Quiz literally means a competition in which a group of participants (or one participant) answer the questions, perform the proposed tasks (Mykhalchuk, 2020). Quizzes can be conducted for one person and for an unlimited group of people. They are regularly used in the educational process during studying foreign languages, improvement of speech and communication skills, the formation of high-level language competence. For example, after passing the educational-thematic block, an online quiz is conducted based on the acquired material. The questions and tasks of creative and analytical nature constitute the basis of the competition. Such tasks are thoroughly selected and discussed by the team of authors: too easy tasks do not attract enough attention of students, and difficult and confusing ones irritate and distract from the topic.

Secondly, it is worth deciding on the content, as the learning positions should be interesting and clear for all participants. It should be emphasized that the use of multimedia in the educational process contributes to educational process.

Thirdly, having compiled a question, it is worth considering and clearly algorithmize the course of the game. The competition can be team or individual; the right to choose tasks and questions should belong to the mediator or players according to random selection. If a certain team is playing, one should additionally note the most active players, and one should create separate rating tables. This increases the interest and concernment of students in the game process. The complexity of the questions may remain the same or may be changed during the game. There should be a reward for the most difficult questions - more points are given. Then the points are calculated and the winners and prize-winners are awarded.

A sufficient number of online quizzes have appeared with the development of Internet technologies, participation in which requires contact communication; it seems very good in conditions of free education. Such forms enable large groups of people located in different cities, countries, and even continents to interact and learn.

"Online quizzes were found to be an effective mechanism for incentivizing student completion of preparatory work, enhancing active learning (such as through in-class discussions), and were relatively time efficient from the perspective of the educator" (Cook \& Babon, 2017). "Quizzes positively affect the effectiveness and attractiveness of blended learning" (Spanjers et al., 2105). In general, students have a positive attitude towards online quizzes; there is a positive interconnection between high grades and a positive attitude towards online quizzes (Cohen \& Sasson, 2016), see Table 2.

Table 2. Student assessment of quizzes (Cook \& Babon, 2017)

\begin{tabular}{ccccc}
\hline Year & Total no. students & \multicolumn{3}{c}{ Student assessment } \\
\cline { 3 - 5 } & & Positive & Mixed & Negative \\
\hline 2013 & 121 & $6(73 \%)$ & $2(9 \%)$ & $4(18 \%)$ \\
2014 & 106 & $5(68 \%)$ & $2(9 \%)$ & $5(23 \%)$ \\
2015 & 231 & $11(61 \%)$ & $1(6 \%)$ & $6(33 \%)$ \\
Total & - & $42(68 \%)$ & $5(8 \%)$ & $15(24 \%)$ \\
\hline
\end{tabular}

When quizzes were available in blended learning, but not in the more traditional condition, the effectiveness was higher than when quizzes were available in both conditions and satisfaction was higher than when no quizzes were present in both conditions. Previous meta-analyses examined similar moderator variables. However, their moderator variables included more than only quizzes and their moderator analyses were not or not only focused on blended learning. Sitzmann, Kraiger, Stewart and Wisher (2006) tested the effects of practice and feedback in moderator analyses for the effect sizes for learning outcomes of fully online learning compared with more traditional learning. Their variable 'practice' was broader as our variable quizzes, because it included in addition to practice exams, which 
could be a type of quiz or self-test, also other instructional aspects. Both practice and feedback appeared to be significant moderators, which is in line with our findings. Means, Toyama, Murphy and Baki (2013) examined the effects of opportunity to practice and feedback provided in online and blended learning conditions in moderator analyses for a combination of effect sizes for online and more traditional learning and blended and more traditional learning. In contrast to the findings of our moderator analyses and those of Sitzmann et al. (2006), they did not find significant effects of the moderators. This implies that in their analyses no significant differences were found between studies differing with regard to the presence or absence of opportunities to practice or to receive feedback in the experimental learning environments.

\subsection{Advantages of Quiz Techniques}

Some researchers and educational institutions, where ICTs have been introduced, have positively assessed the integration of informatization into the educational process. This section presents the experience of mastering as a supplement or replacement of the traditional methods in the structure of academic education. Many researchers talk about the popularity of new teaching aids.

During the research, a number of authors have mentioned the positive aspects of the introduction of e-learning tools, as well as the involvement of social networks (Facebook) and game applications.

1. Availability of educational content (electronic lecturers, simulators, educational materials).

2. Development and implementation of intellectual games with the use of distance communication.

3. Simulation of the learning process through the game.

4. Ensuring an open form of education during travel restrictions and direct communication.

5. Possibility to hold interactive conferences on different platforms.

6. Creating an informatized control system with a competitive element.

7. System support.

8. Creating original (animation, photos, videos, mixed type) presentations.

9. Providing opportunities for research, creative, project activities of students.

\subsection{The Process of Integration IT Technologies into the Educational Space of Higher Education}

The main transitional and positive implementation of ICT in the educational space of higher education can be provided: the speed of communication, the use of distance learning, learning among educational institutions, technical knowledge as teachers (see Table 3).

Table 3. Issues of ICT implementation into the educational space of higher education (Mykytiuk et al., 2020; Sereda, 2014)

\begin{tabular}{|c|c|}
\hline Advantages & Disa \\
\hline $\begin{array}{l}\text { 1. In a situation of impossibility of personal } \\
\text { communication teacher-student - convenient, } \\
\text { accessible, flexible. }\end{array}$ & $\begin{array}{l}\text { 1. Academic workload concerning the creation, } \\
\text { implementation and support of the program. } \\
\text { 2. Insufficient technical and technological base. }\end{array}$ \\
\hline 2. Improving the quality of education. & \\
\hline 3. Facilitating the mastery of complex topics. & \\
\hline $\begin{array}{l}\text { 4. Popularization of modern and rather complex } \\
\text { courses. }\end{array}$ & tency of course design and students' \\
\hline $\begin{array}{l}\text { 5. Improving the technical knowledge and } \\
\text { competence of teachers and students. }\end{array}$ & cult to control the learning process. \\
\hline 6. Expanding students' opportunities. & ing, filling \\
\hline $\begin{array}{l}\text { 7. Exp } \\
\text { for the }\end{array}$ & he educ \\
\hline
\end{tabular}

\section{Discussion}

\subsection{A Comprehensive Approach to the Implementation of Online Quizzes}

The presented study considers online quizzes as components of the implementation of open education, taking into account all the problems and shortcomings of the introduction and implementation of ICT in the educational process (Vdovychyn \& Iatsyshyn, 2013). The program's implementation of introduction of online quizzes also provides 
complex work of the analytical agency, higher educational institutions, and libraries.

\subsection{ICT System in Pedagogical Education: Experience in Implementing an Online Quiz Projects}

The topic of ICT and new modern educational technologies was often considered in the Eastern European educational space, but the vast majority of works were general and theoretically centered (Goncharenko, 2011). There are many works that consider practical cases in world pedagogy (Mykytiuk et al., 2020; Synorub et al., 2019). They became the starting point for the consideration of the ICT system and directly modern educational technologies for training linguists, among which there are game technologies, test tasks of various kinds.

NGO "Center for Analytics and Investigations", the fact-check project "BezBrehni" implements the educational project "Interactive quizzes as a tool of media literacy to counteract fake news and misinformation" with the support of the Academy of Ukrainian Press and Internews Ukraine (Mykhalchuk, 2020). Within the framework of the current project, the specialists of the organization and universities have introduced a new online format for the assimilation of knowledge and skills by vocational students - online quizzes. The project partners are regional libraries and educational institutions - universities. In total, 10 organizations from different regions of Ukraine have been involved in this initiative. The whole project consisted of 3 stages.

The first stage involved an open webinar for 10 representatives of regional educational institutions and libraries. The consultations are held within the framework of the webinar, as well as trainings are conducted for direct local curators, executors of further project activities with groups of students, project participants. A separate block of the webinar has been devoted to the methodology of conducting online quizzes, briefing on the technical features of preparation and organization of participants. Along with this, a workshop has been held on solving tasks and exercises that will be used during online quizzes. Participants - consultants have been presented with 5 typical exercises for independent learning during the second stage of the project.

At the second stage of the project's implementation, each regional curator formed a team of 5 people from proactive youth (students - philologists ) ( 2 - reserve students). Teachers worked through typical exercises for online quizzes in distance or online format with them, as well as instructed on the technical features of the online event's features.

At the third stage of the project, three online quizzes were held, followed by two more online quizzes in two weeks. Two teams under the guidance of a curator were involved in each quiz. Quizzes were conducted in online format each participant could join the event at a specified time from any geographical location. This is one of the great advantages within the conditions of restricting personal communication - there is no need for a centralized team.

Each online quiz lasts up to three hours. During the training-practical "competition" in 5 (five) rounds, up to 10 questions were considered, which related to various topics and aspects of media literacy, analytical and creative work with the text. According to the technology of the game, the teams received questions, and they had to process them within the set time (three - five minutes) in separate online classrooms, created for each team. At the end of the discussion time, answers were given on the general online platform of the event.

At first, the game's mentors accepted the answers, established their correctness, provided extended information from the questions discussed in order to deepen the knowledge and skills of the participants, then the project leader submitted his comments. At the end of the quiz, the chairman announced the score and the conditional winners. All participants were awarded with certificates, see Figure 1.

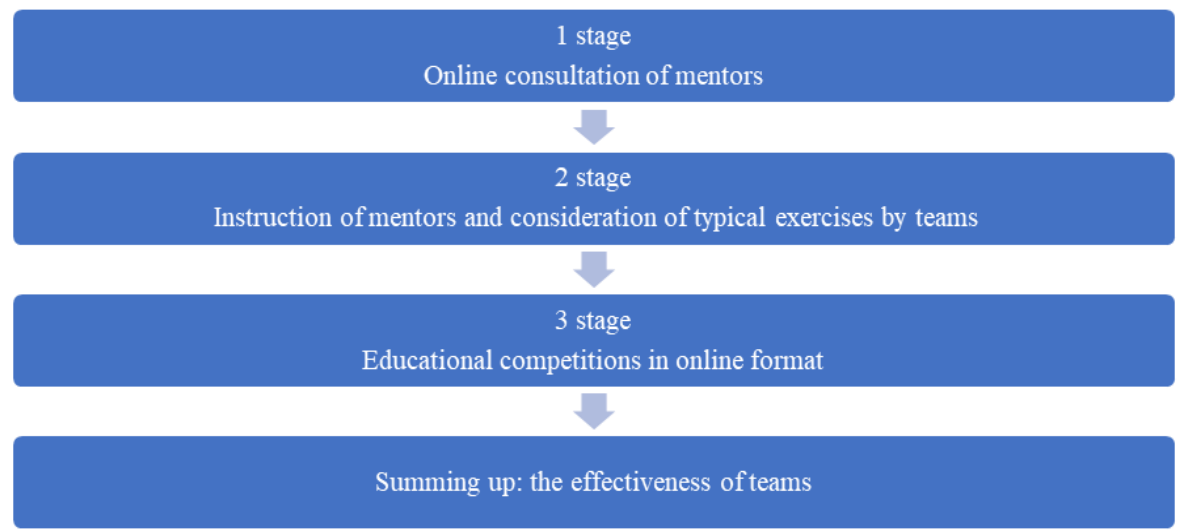

Figure 1. Stages of the project "Interactive quizzes as a tool of media literacy to counteract fakes news and misinformation" (Mykhalchuk, 2020) 


\subsection{Readiness of Universities to Implement the Project}

Compulsory and universal computerization of universities contributes to the introduction of Internet technologies, the involvement of social electronic networks in the education system (Mervat, 2016). This has become especially important within the conditions of forced distance learning - open forms of education. In fact, open forms create opportunities for education. Students and teachers are constantly communicating through various forms of electronic communication (E-mail, Skype, ICQ). It is also important to have educational content presented in electronic format - this make it possible to obtain free and efficient access to the initial content. Vdovychyn and Iatsyshyn (2013) consider the creation of such educational content an advantage, an argument in favor of the use of all forms of online education. In addition, the operational ability to contact a teacher or a working group of students at any time indicates a great similarity between such forms and full-time studies (Vdovychyn \& Iatsyshyn, 2013), see Figure 2.

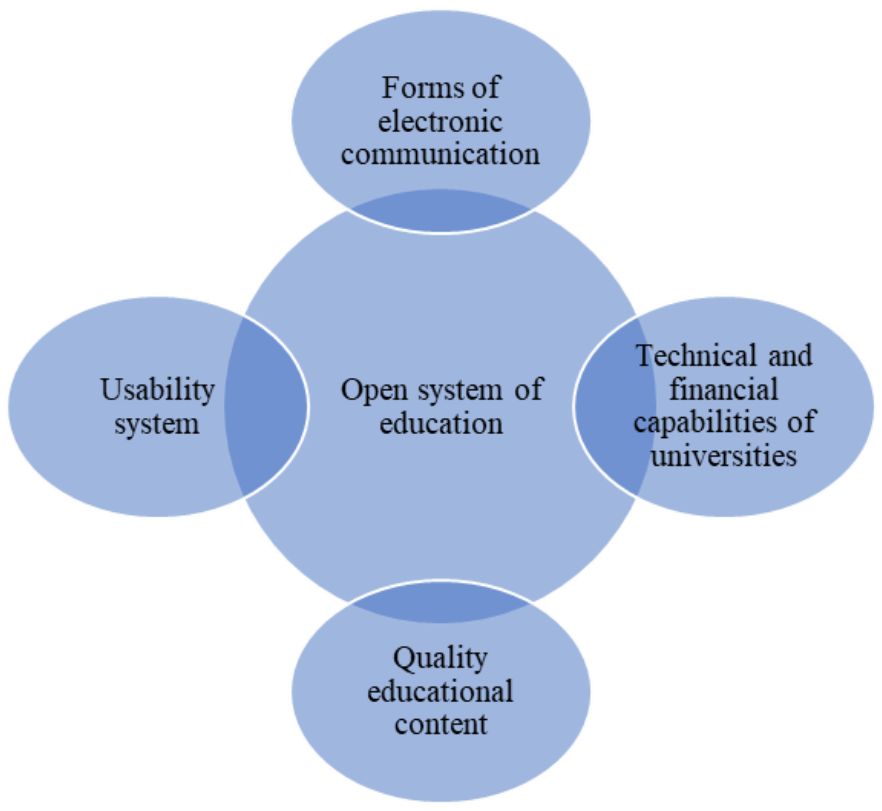

Figure 2. Conditions for successful implementation of open education projects with involving ICT (Sereda, 2011; 2014; Vdovychyn \& Iatsyshyn, 2013)

\subsection{Personnel Readiness}

An effective and modern system of ICT education is an important condition for improving the quality of academic education. It is necessary to train teachers, students and professionals who use the system and tools of new computerized learning technologies for the successful implementation of ICT. Each participant (and administration) who plans to use ICT in the educational process, should have the necessary information literacy. The teaching staff, including the administration, should also understand how to use such technologies. Thus, the British experience shows that the system of certification of professionals, involved in the learning process, is an important component of staff readiness. The presence of a system of regular certification will simplify the implementation of ICT; it will open up prospects for continuous modernization (Sereda, 2011;2014) and increase the adequacy of assessments of ICTs used.

\subsection{Ways to Assess Knowledge}

A continuous process of assessing knowledge should be compulsory, such as to prevent students' low performance level. Online quizzes with technologically modern computerized fields of interaction have key indicators that will make it possible to monitor the progress of affairs. The same can be observed in groups on social networks created for educational purposes for teachers - philologists (Facebook, Telegram, Viber, Google platforms). Each thematic component of educational content should be equipped with a short test, or end with heuristic creative tasks.

The plagiarism problem, the observance of the rules of academic virtue is not too urgent for the application of new educational technologies in the system of courses for teachers - philologists, forasmuch as the creative and active nature of tasks, group forms of online work do not create conditions for unethical behavior and fraud. 


\section{Conclusion}

This study has considered the ways and prospects of using high-tech ICT in the educational process of training teachers of the humanitarian direction. The difficulties and positive aspects of informatization movement of pedagogical education in modern conditions have been outlined, when the need arises to resort to forms of open education, such as distance learning. The experience of working with online tools designed for learning, mastering, acquiring new knowledge of different levels and nature has been considered. In particular, special attention has been paid to the development of game and competitive methods that actively use ICT. This coincides with the conclusions presented in a number of works by representatives of the NAPS of Ukraine and world investigations on this issue.

It is clear that comprehensive approach should be ensured within the conditions of increased interest in the integration of open education into the educational process during the training of teachers - philologists. This is a guarantee of the successful introduction of modern technological forms of education.

Further investigations will focus on highlighting the stages and creating conditions at universities for the successful implementation of ICT. It will help develop step-by-step recommendations for the integration of interactive forms of learning use the latest technology, which is one of the social conditions for the successful development of modern pedagogical education. The described experience requires further expansion, transformation and introduction of the most effective experience of the academic level of education.

\section{References}

Bikov, V. Yu. (2009). Models of organizational systems of open education: monograph. Kyiv, Ukraine: Atika.

Buzhikov, R. P. (2011). Didactic potential of Internet technology in the modern education system. Problemi osviti, 66, 40-44.

Cohen, D., \& Sasson, I. (2016). Online quizzes in a virtual learning environment as a tool for formative assessment. Journal of Technology and Science Education, 6(3), 188-208. http://dx.doi.org/10.3926/jotse.217

Cook, B. R., \& Babon, A. (2017). Active learning through online quizzes: better learning and less (busy) work. Journal of Geography in Higher Education, 41(1), 24-38. https://doi.org/10.1080/03098265.2016.1185772

Goncharenko, S. U. (2011). Ukrainian pedagogical encyclopedic dictionary. Rivne: Volins'ki oberegi.

Gorman, M. (2019). Local business video marketing - 2020 guide, strategies, statistics. My Simple Show. Retrevied from: https://www.mysimpleshow.com/local-businessvideo-marketing/

Kilchenko, A. V., \& Romenets, Yu. V. (n.d.). Methods and organization of the All-Ukrainian Online competition "Teacher-innovator". Retrevied from: http://lib.iitta.gov.ua/107141/1/\%D0\%9A\%D0\%B8\%D0\%BB\%D1\%8C\%D1\%87\%D0\%B5\%D0\%BD\%D0\%B A\%D0\%BE.pdf

Koval, T. I. (2009). Training of higher school teachers: information technologies in pedagogical activity. Kyiv, Ukraine: NLU.

Mason, R. (2006). Learning technologies for adult continuing education. Studies in Continuing Education, 28(2), 121-133. https://doi.org/10.1080/01580370600751039

Means, B., Toyama, Y., Murphy, R. \& Baki, M. (2013). The effectiveness of online and blended learning: A meta-analysis of the empirical literature. Teachers College Record, 115(3), 030303.

Mervat, A. (2016). Using Facebook to develop grammar discussion and writing skills in English as a foreign language for university students. Sino-US English Teaching, 13(12), 932-952. https://doi.org/10.17265/1539-8072/2016.12.004

Mykhalchuk, L. (2020). The first online quiz of the project "Interactive quizzes as a tool of media literacy to counter fakes and misinformation about COVID-19" took place. Liberty Space. Retrevied from https://www.libertyspace.org.ua/2020/06/25/chytachi-biblioteky-vizmut-uchast-u-proekti-interaktyvni-kvizy-iak -instrument-mediahramotnosti-dlia-protydii-fejkam-i-dezinformatsii/

Mykytiuk, S., Lysystska, O., \& Melnikova, T. (2020). Facebook group as an educational platform for foreign language acquisition. Postmodern Openings, 11, 131-157. https://doi.org/10.18662/po/11.1sup1/127

Network partnership in learning. (n.d.). Retrevied from: http://ua.partnersinlearningnetwork.com.

Ovcharuk, O. V. (2006). Conceptual approaches to the open education technologies application and dictance learning in abroad and its role in the education modernization processes. Information Technologies and Learning Tools, 
1(1). https://doi.org/10.33407/itlt.v1i1.292

Sereda, Kh. V. (2014). Theoretical basis of informatization of management of scientific researches in the sphere of pedagogical sciences. Information Technologies and Learning Tools, 42(4), 181-199. https://doi.org/10.33407/itlt.v42i4.1051

Sereda, Kh.V. (2011). "Partners in Learning Network" is the Ukrainian segment of global association of teachers. Naukovij chasopis, 28(5), 223-227.

Sitzmann, T., Kraiger, K., Stewart, D., \& Wisher, R. (2006). The comparative effectiveness of web-based and classroom instruction: A meta-analysis. Personnel Psychology, 59(3), 623-664. https://doi.org/10.1111/j.1744-6570.2006.00049.x

Spanjers, I. A., Könings, K. D., Leppink, J., Verstegen, D. M., de Jong, N., Czabanowska, K., \& van Merrienboer, J. J. (2015). The promised land of blended learning: Quizzes as a moderator. Educational Research Review, 15, 59-74. http://doi.org/10.1016/j.edurev.2015.05.001

Stavytska, I. V. (2015). Information and communication technologies in education. Teacher. Retrevied from: https://teacher.at.ua/publ/innovacijni_tekhnologiji_navchannja/informacijno_komunikacijni_tekhnologiji_v_osv iti/63-1-0-18503

Synorub, H. P., Medynska, O., Poplavska, N., Medynska, O. Ya., \& Poplavska, N. M. (2019). Crossmedia as an innovative technology in training the humanities students in higher school. Information Technologies and Learning Tools, 70(2), 257-270. https://doi.org/10.33407/itlt.v70i2.2762

Tashakori, S., \& Haghighat, S. (2019). Designing the intelligent system detecting a sense of wonder in english speech signal using fuzzy-nervous inferenceadaptive system (ANFIS). Broad Research in Artificial Intelligence and Neuroscience, $10(1), 55-63$.

Vdovychyn, T., \& Iatsyshyn, A. (2013). Using technology of open education for the informatization educational process. Information technology of open education for the informatization educational process, 4(41), 134-140. https://doi.org/10.14308/ite000438

Villano, M. (2007). Social revolution. Campus Technology, 20(5), 40-45.

Vykhrushch, A. V., Hnatyshyn, S. I., Klymenko, A. O., Medynska, O. Ya., Synorub, H. P., \& Horpinich, T. I. (2019). Development of information culture of students of humanitarian specialities. Information Technologies and Learning Tools, 72(4), 152-167 https://doi.org/10.33407/itlt.v72i4.2922

Vysotska, O. E. (n.d.). Open education as a factor advancing development of society. Retrevied from: https://virtkafedra.ucoz.ua/el_gurnal/pages/vyp7/konf1/Vysocka.pdf

Zabolotny, V. F. (2010). Didactic bases of application of multimedia in formation of methodical competence of future teachers of physics. PhD abstract thesis. M. O. Dragomanov National Pedagogical University, Kyiv, Ukraine.

Ivanova, I. B. (2020). The "Nakipilo" media project as a successful experience of building independent media. In II All-Ukrainian scientific-practical conference: Actual problems of media space (pp. 207-210). Kyiv, Ukraine: Institut zhurnalistiki. 